\title{
Selenium Nanoparticles Ameliorative Effect on Acetaminophen Hepatotoxicity in Male Mice
}

\author{
Mohammad S. AL-Harbi' ${ }^{1}$, Sayed A. M. Amer ${ }^{2,3}$ \\ ${ }^{1}$ Department of Biology, Faculty of Science, Taif University, Taif, Saudi Arabia; ${ }^{2}$ College of Forensic Sciences, Naif \\ Arab University for Security Sciences, Riyadh, Saudi Arabia; ${ }^{3}$ Zoology Department, Faculty of Science, \\ Cairo University, Giza, Egypt
}

Correspondence to: Sayed A. M. Amer, sayed.amer@nauss.edu.sa

Keywords: SeNPs, Mice, APAP, Hepatotoxicity, Antioxidant

Received: June 22, $2017 \quad$ Accepted: July 17, $2017 \quad$ Published: July 20, 2017

Copyright $\odot 2017$ by authors and Scientific Research Publishing Inc.

This work is licensed under the Creative Commons Attribution-NonCommercial International License (CC BY-NC 4.0).

http://creativecommons.org/licenses/by-nc/4.0/

\section{(c) $)(9)$ Open Access}

\section{ABSTRACT}

Selenium nanoparticles (SeNPs) have been widely used as anti-inflammatory and anti-toxic agent. The present study used Bacillus tequilensis for biosynthesizing SeNPs from sodium selenite $\left(\mathrm{Na}_{2} \mathrm{SeO}_{3}\right)$ and investigated its ameliorative effects on acetaminophen (APAP) hepatotoxicity in male mice. The results indicated that Alanine transaminase (ALT), aspartate aminotransferase (AST) and alkaline phosphatase (ALP) significantly elevated in mice treated with APAP, while other liver markers (total proteins and albumin) did not change. SeNPs either alone or in combination with APAP showed ameliorative effects on liver enzymes to some extents where their activities decreased to be insignificant with those of normal group. A slight variation was shown in total antioxidant capacity (TAC). Histopathologically, the hepatocytes of the mice treated with APAP showed cloudy swelling and vacuolar degeneration, while those treated with SeNPs or both SeNPs and APAP appeared more or less histologically normal. In conclusion, SeNPs can be used to improve or replace today's therapies of APAP hepatotoxicity.

\section{INTRODUCTION}

Selenium nanoparticles (SeNPs) have been produced by many bacterial species like Pantoea agglomerans, Zooglea ramigera, Pseudomonas alcaliphila, Bacillus subtilis, Bacillus cereus and Duganella sp. [1-3]. Selenium respiring bacteria Sulfurospirillum barnesii, Bacillus selenitireducens and Selenihalanaerobacter shriftii also produced SeNPs in anaerobic conditions [4]. However, production in aerobic condition is much easier than in the anaerobic condition. Anaerobic biogenesis is a tiresome and difficult process [1]. 
Acetaminophen (APAP) is well-known drug inducing severe oxidative stress allowing mitochondrial permeability transition in liver cells. Liver cells eliminate free radicals and face apoptosis as a result of the drug hepatotoxicity [5]. Several studies tackled the hepatotoxic effect of APAP in male and female mice and rat [6-13].

In male albino rats, SeNPs have been used as an antioxidant against the hepatic damage caused by parasitism [14] and neural and renal APAP toxicity. SeNPs also showed anti-inflammatory and analgesic effects in irradiated rats [15]. It is therefore, necessary to investigate its ameliorative role against APAP hepatotoxicity in male mice.

\section{MATERIALS AND METHODS}

\subsection{Experimental Design and Biochemical Assays}

Twenty male mice weighed 30 to $40 \mathrm{~g}$ were primarily divided into 4 groups ( 5 individuals per group). The animals were put in plastic cages, fed normally and left for acclimatization for 10 days in good ventilated room at Taif University of Western Saudi Arabia. The control mice administrated tap water. The second received APAP dissolved in water with the human therapeutic dose ( $75 \mathrm{mg} / \mathrm{kg}$ body weight). The third group was taken SeNPs $\left(0.001 \mathrm{~mol}\right.$ of $50 \mathrm{~nm}$ SeNPs dispersed in liter $\left.\mathrm{ddH}_{2} \mathrm{O}\right)$ while the fourth group was subjected to a mixture of APAP and SeNPs. After 21 days administration, blood samples were obtained from the anesthetized animals while liver tissues were taken immediately after dissection. Liver enzymes; ALT, AST and ALP and the antioxidants super oxide dismutase (SOD), total antioxidant capacity (TAC) and malondialdehyde (MDA) were measured by kits prepared by authors cited in Dakrory et al. [16].

\subsection{Production and Description of SeNPs}

SeNPs were prepared by reducing selenium ions with Bacillus tequilensi. Bacterial strain was grown up in $100 \mathrm{ml}$ nutrient broth incubated at $37^{\circ} \mathrm{C}$. After $18 \mathrm{hrs}$, the incubated culture was centrifuged at 7000

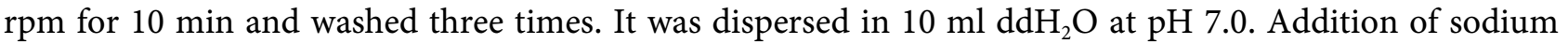
selenite $\left(\mathrm{Na}_{2} \mathrm{SeO}_{3}\right)$ was undertaken in order to make Selenium concentration to be $1 \mathrm{mM}$. Further incubation was happened for 24 hrs. Observation of the biomass turning red was a marker of convenient formation of SeNPs [17]. Centrifugation at the same conditions followed by washing was conducted to collect the bacterial biomass. The precipitate was resuspended in $5 \mathrm{~mL}$ Phosphate Buffer at $\mathrm{pH} 7.4$ followed by ultrasonication (130 W, 10 min, Vibracell VCX-130; Sonics and Materials Inc., CT, USA). The suspension was filtered with $0.45 \mathrm{~mm}$ and $0.2 \mathrm{~mm}$ pore size cellulose acetate filters (Advantec, Tokyo, Japan). Again, centrifugation of the filtrates was done at $10,000 \mathrm{rpm}, 4^{\circ} \mathrm{C}$ for $30 \mathrm{~min}$ and the pellet was suspended in 5 $\mathrm{mL}$ of ultrapure water for further study. Characterization of the formed particles was conducted $[3,18]$. The produced SeNPs were described by UV-Vis spectroscopy (Perkin Elmer, Lambda 25) with scanning range of $200-900 \mathrm{~nm}$ at $1 \mathrm{~nm}$ resolution.

\subsection{Transmission EM (TEM) and X-Ray Diffraction (XRD) Analysis}

After centrifugation, a drop of the synthesized SeNPs was placed on the carbon coated copper grids and kept under vacuum desiccation overnight before loading onto a specimen holder. Size, morphology and composition were recorded by TEM operated at $120 \mathrm{k}$ accelerating voltage (JTEM 1230, Japan, JEOL) with selected area electron diffraction. XRD analysis was conducted by an automated diffract meter (Philips type: Pw1840) at 0.02 step size, 20 in $2^{\theta} / \mathrm{min}$ scanning rate and a $2^{\theta}$ range from 100 to 700 . Powder patterns indexing and unit cell parameters least squares fitting using the software X'Pert High score Plus was undertaken.

\subsection{Liver Histology}

For the histological preparations of liver tissues, fixation, preservation, embedding, dehydration, 
deparaffinization, rehydration was conducted as described by Amer et al. [19]. H\&E staining was undertaken according to protocols of Bancroft et al. [20]. Photomicrographing [19] was also done.

\subsection{Statistics}

The results were statistically manipulated by ANOVA packaged in SPSS version 11.0. LSD was conducted for the paired comparisons.

\section{RESULTS AND DISCUSSION}

Observation of the culture incubated with $\left(\mathrm{Na}_{2} \mathrm{SeO}_{3}\right)$ showed a change from yellow to red (Figure 1) which is characteristic for SeNPs. The red color [3] which was due to the excitation of surface plasmon vibrations in SeNPs provided a convenient spectroscopic signature of the nanoparticles formation $[1,4]$. No color change could be demonstrated in cultures without selenium dioxide as negative control. The UV-Vis absorption spectra recorded a strong resonance at $335 \mathrm{~nm}$ (Figure 1). However, no absorption peak appeared after addition of salts indicating that a constituent of the culture medium was not involved in SeNPs.

The biosynthesized SeNPs shown in TEM image were spherical and polydispersed with average diameter range of 10 - $55 \mathrm{~nm}$ (Figure 2(a)). Bacillus megaterium and Bacillus cereus reduced selenite to SeNPs after $40 \mathrm{hrs}[1,21]$.

Bacillus sp. MSh-1 produced spherical SeNPs with $80 \mathrm{~nm}$ diameter $[3,18]$. We consider this study the first that reported the formation of small SeNPs by Bacillus tequilensis. The XRD analysis for the biosynthesized selenium indicated three intense peaks in the whole spectrum of $2 \mathrm{q}$ values ranging from 5 to 80 (Figure 3). The diffractions peak at $2 \mathrm{q}$ value of 23.780, 29.797 and 43.878 can be indexed to the (100), (101) and (102) planes of the face-centered cubic ( $\mathrm{fcc}$ ) red elemental selenium, respectively [21].

As AL-Harabi et al. [22] concluded, liver was the main tissues clearly influenced significantly by nonoparticles treatment. ALP, AST and ALT were increased significantly $(\mathrm{p}<0.01)$ in the group received APAP indicating the toxic effect of the drug. Several investigations accumulated similar findings [6-13].

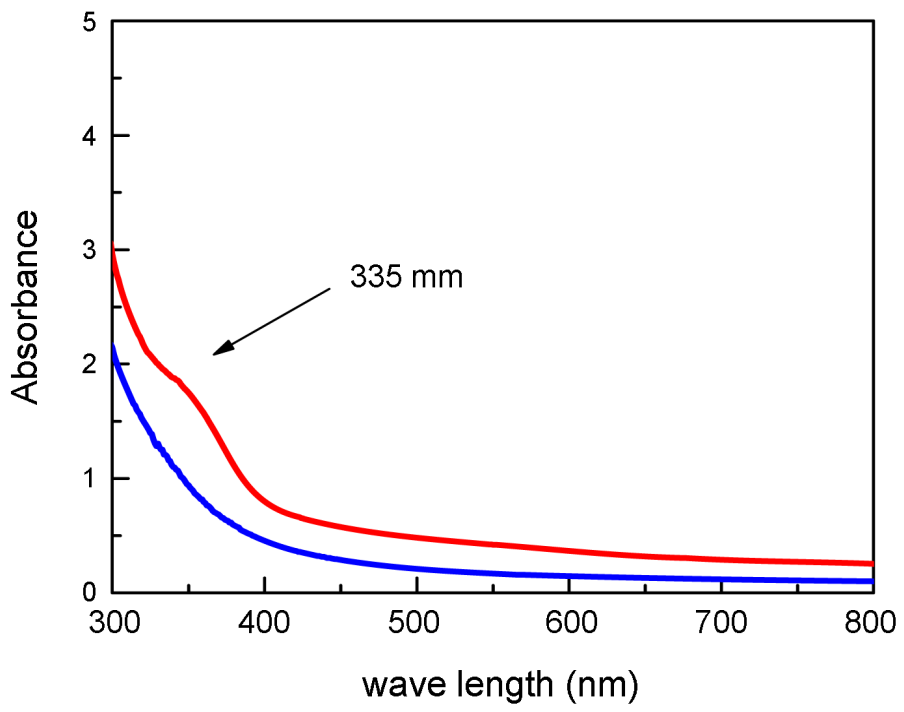

Figure 1. UV-Visible absorption spectra of bacterial synthesized SeNPs. The typical surface plasmon resonance (SPR) band is shown at $335 \mathrm{~nm}$ (red line). The blue line refers to the spectrum of the negative control. 


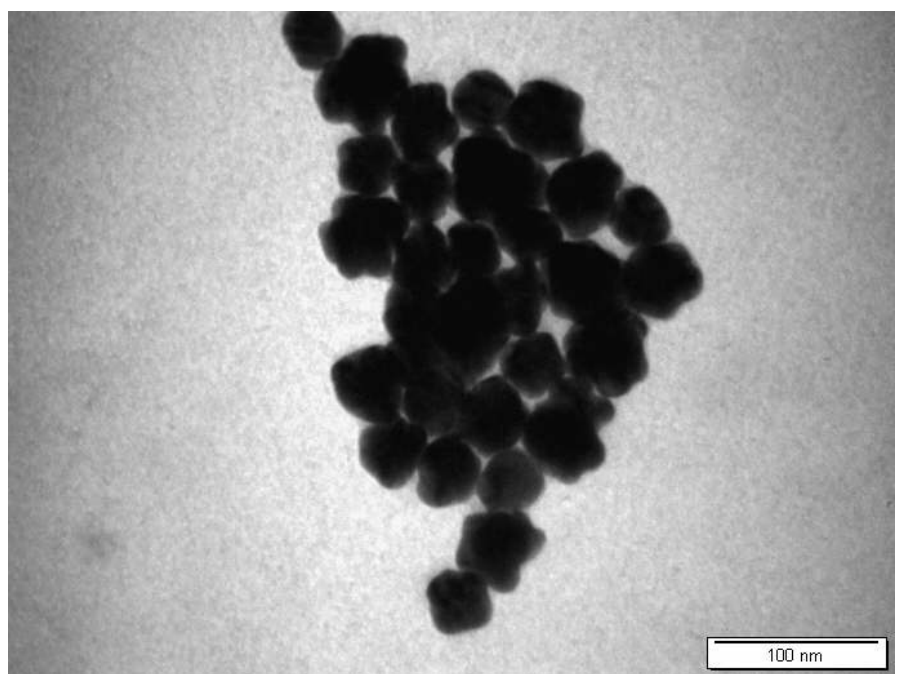

(a)

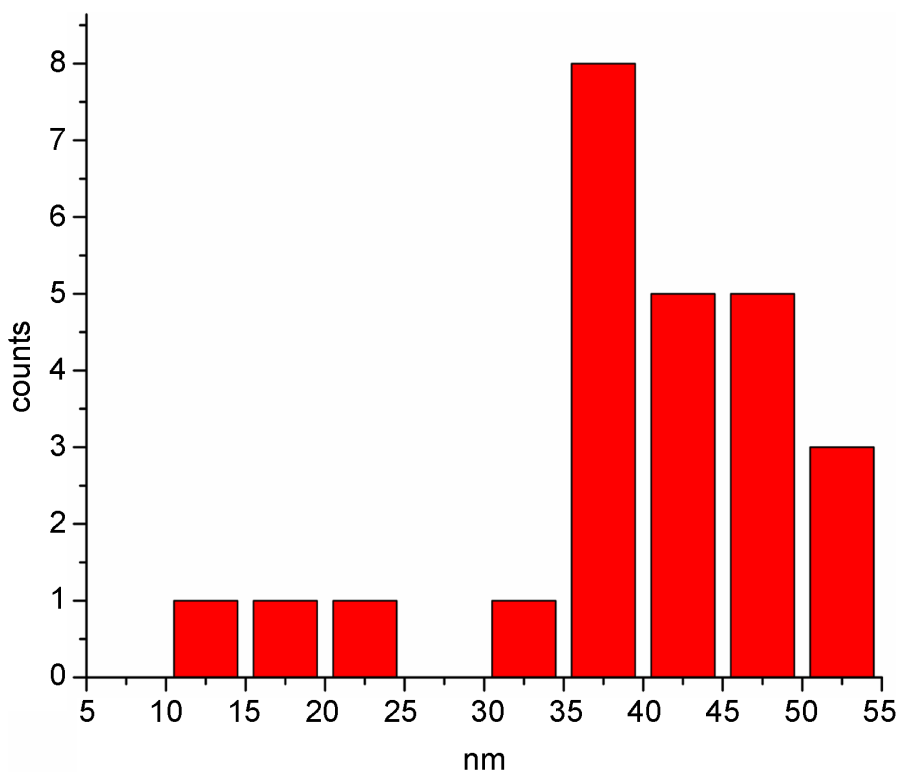

(b)

Figure 2. TEM micrographs recorded from drop-cast films of bacterial synthesized SeNPs (a) and its particle size distributions (b).

The enzymes activity in the groups treated with SeNPs immediately after APAP supplementation or in combination with APAP showed normal enzyme activity with no significant difference to that of the control (Table 1). Unfortunately, the two main liver markers (albumin and total proteins) did not exhibit significant variations in either control or treated groups. Similar findings were revealed by Oleaga et al. [23] where, doxorubicin which is considered hepatotoxic, did not show any effect on albumin. No significant influence in the liver antioxidants has been recorded, except slight changes $(p>0.05)$ in the group treated with APAP and SeNPs in MDA and in SeNPs group for TAC. This can be interpreted with the toxicity of SeNPs that enhances the liver cells to eliminate free radicals [24]. In conclusion SeNPs, with very low concentration, generally protected liver against oxidative damage induced by APAP in mice.

Liver histology of the control group appeared more or less normal (Figure 4). The organ was divided 


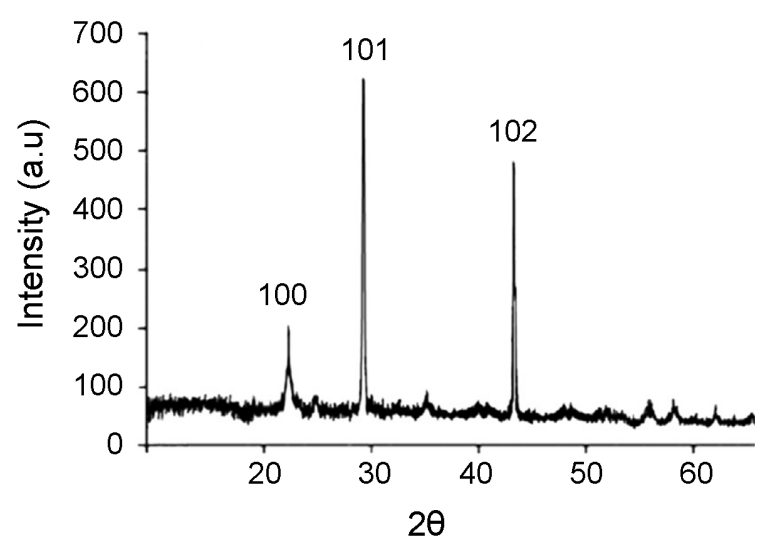

Figure 3. XRD pattern of the bacterial SeNPs. The characteristic strong diffraction peak located at $29.79 \mathrm{u}$ is ascribed to the (101) facets of the face-centered cubic elemental Se structure.

Table 1. Mean \pm SE of hepatic enzymes and antioxidant activities in male mice supplemented APAP, SeNPs, APAP + SeNPs for 21 days. Significant differences between was $\left(*=\mathrm{p}<0.05 ;{ }^{*}=\mathrm{p}<0.01\right.$; $* * *=p<0.001)$ among the different treatments according to LSD of ANOVA test. Symbols for significant differences were as follows: $\diamond$ (between control and APAP groups), ++ (between APAP and SeNPs groups), •. (between APAP and APAP + SeNPs groups), \$\$ (between Control and APAP + SeNPs groups) and $¥$ (between APAP and SeNPs groups). Symbols for significant differences of antioxidants (malondialdehyde $=\mathrm{MDA}$, total antioxidant $=\mathrm{TAC}$ and superoxide dismutase $=\mathrm{SOD}$ ) were as follows: $\$$ (between APAP and SeNPs groups), $\checkmark$ (between control and APAP + SeNPs groups). * refers to significance difference estimated by ANOVA among groups.

\begin{tabular}{cccccc}
\hline Variable & C & APAP & SeNPs & APAP + SeNPs & f-value \\
\hline ALP (U/L) & $23.03 \pm 3.2$ & $36.06 \pm 3.3,++, \bullet$ & $26.3 \pm 1.2$ & $17.8 \pm 2.2$ & $7.3^{* *}$ \\
AST (U/L) & $86.1 \pm 16.3$ & $226.4 \pm 8.9,++, \bullet$ & $123.9 \pm 27.2$ & $84.9 \pm 3.5$ & $14.5^{\star * *}$ \\
ALT (U/L) & $75.6 \pm 15.9$ & $153.3 \pm 6.9,++, ¥$ & $87.7 \pm 11.2$ & $117.1 \pm 9.4 \$ \$$ & $14.4^{\star * *}$ \\
Albumin (g/dl) & $4.1 \pm 0.5$ & $4.2 \pm 0.1$ & $3.5 \pm 0.4$ & $4 \pm 0.1$ & 0.74 \\
Protein (g/dl) & $11.7 \pm 1.4$ & $10.2 \pm 1.2$ & $11.5 \pm 0.7$ & $10.4 \pm 0.2$ & 0.48 \\
MDA (nmol/g) & $1289.5 \pm 164.2$ & $1965.8 \pm 149.3$ & $1658.8 \pm 120.7$ & $2229 \pm 432 \bullet$ & 2.9 \\
TAC (mM/g) & $1.5 \pm 0.08$ & $1.4 \pm 0.05$ & $1.6 \pm 0.0 \ddagger$ & $1.6 \pm 0.01$ & $3.6^{*}$ \\
SOD (U/g) & $1904.7 \pm 47.6$ & $7642.8 \pm 829.7$ & $6499.9 \pm 4647.2$ & $4071.5 \pm 928.5$ & 0.47 \\
\hline
\end{tabular}

into hepatic lobules in which the central vein was centrally located and surrounded by hepatic columns. The hepatocytes appeared polyhydral with centrally located vesicular nuclei. Hepatic sinusoids were seen between the hepatic columns. Van kupffer cells were frequently seen. The hepatocytes of the mice treated with APAP had cloudy swelling and vacuolar degeneration (Figure 5(a)). Pericentral necrosis was seen in most cases in which the hepatocytes showed strongly eosinophilic cytoplasm with pyknotic nuclei (Figure 5(b)). Centrolobularly, solitary cells underwent pyknosis in some areas. The blood vessels were dilated and engorged with blood. The hepatic sinusoids were dilated in some areas with mild proliferation of Von 


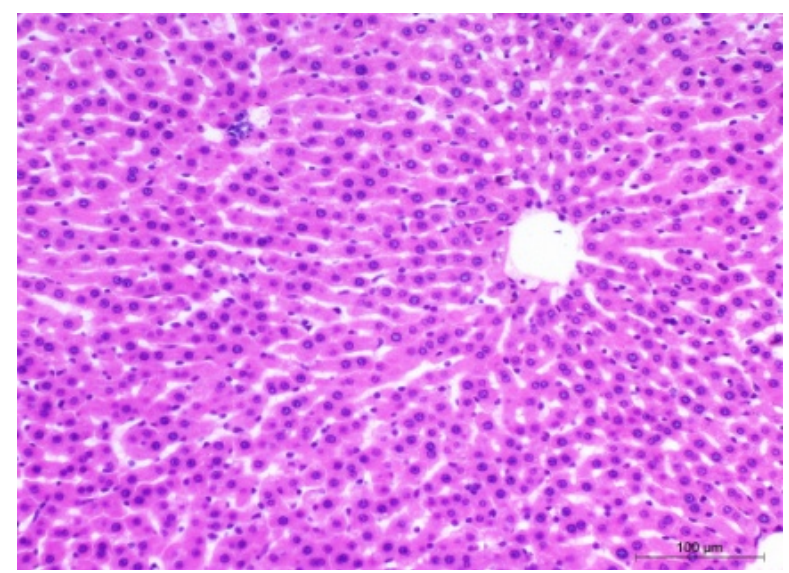

Figure 4. H\&E stained photomicrograph of liver from a control group rat.

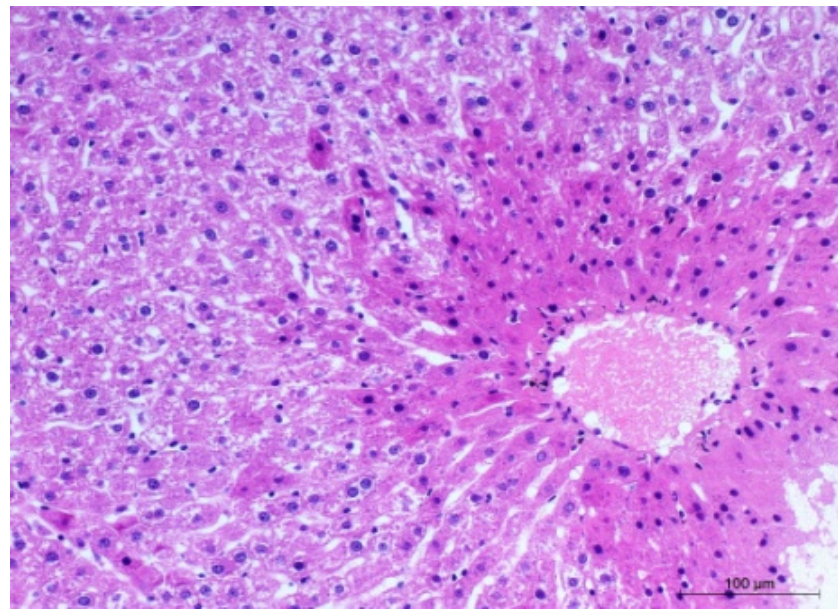

(a)

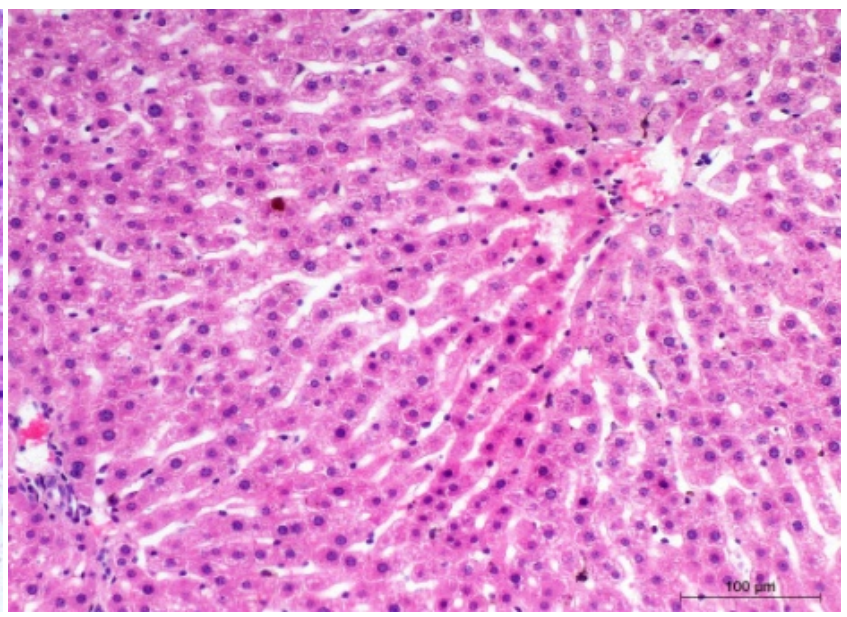

(b)

Figure 5. H\&E stained photomicrographs of rat liver treated with APAP that are showing degenerative changes (a) and hepatocytes with pyknotic nuclei (b).

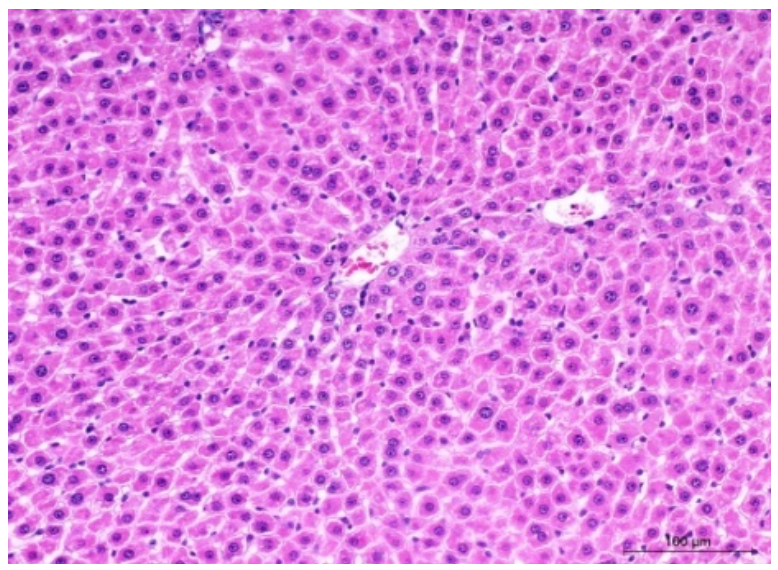

Figure 6. H\&E stained photomicrograph of liver for rat treated with SeNPs. 


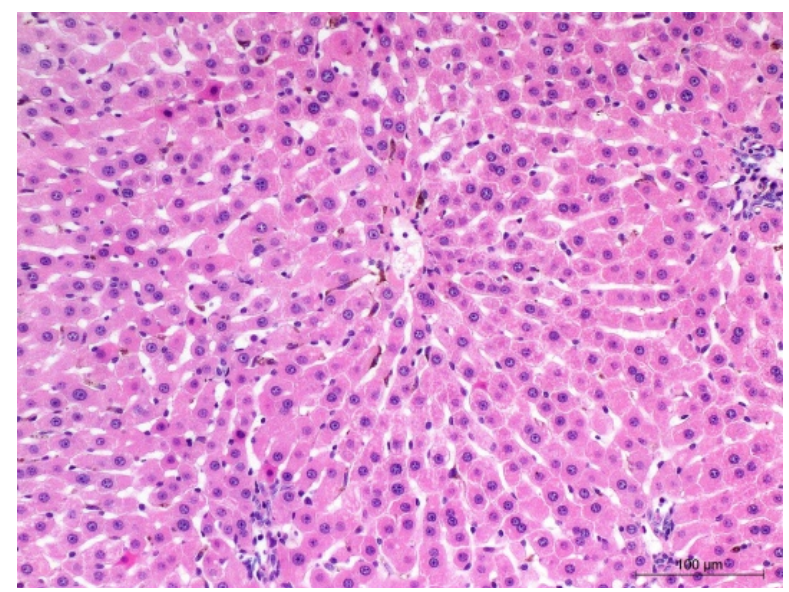

Figure 7. H\&E stained photomicrograph of normal liver for rats treated with both APAP and SeNPs.

kupffer cells. The liver of mice treated with SeNPs appeared more or less histologically normal (Figure 6). No necrotic changes had been recorded. The hepatic lobules were well organized. In some areas, a few cells were very mildly degenerated but without toxic changes. Compared to APAP group, the liver of mice treated with both APAP and SeNPs were markedly improved and the liver appeared normal to more extent. Few cells were still showing very mild degenerative changes and pyknosis (Figure 7). The blood vessels were mildly dilated and congested. No necrotic changes could be seen. Similar damage for liver tissues by APAP has been recorded [25-28]. SeNPs showed also ameliorative effect, histologically, on hepatotoxicity induced by drugs or parasites in several investigations $[14,29]$.

\section{CONCLUSION}

In conclusion, SeNPs can be used to replace today's therapies of APAP hepatotoxicity as the liver enzymes become normal after treatment with the synthesized nanoparticles. Meanwhile, liver histology showed an improvement by SeNPs administration.

\section{REFERENCES}

1. Dhanjal, S. and Cameotra, S. (2010) Aerobic Biogenesis of Selenium Nanospheres by Bacillus cereus Isolated from Coalmine Soil. Microbial Cell Factories, 9, 1-11. https://doi.org/10.1186/1475-2859-9-52

2. Wang, T., Yang, L., Zhang, B. and Liu, J. (2010) Extracellular Biosynthesis and Transformation of Selenium Nanoparticles and Application in $\mathrm{H}_{2} \mathrm{O}_{2}$ Biosensor. Colloids and Surfaces B: Biointerfaces, 80, 94-102. https://doi.org/10.1016/j.colsurfb.2010.05.041

3. Zhang, W., Chen, Z., Liu, H., Zhang, L., Gao, P. and Li, D. (2011) Biosynthesis and Structural Characteristics of Selenium Nanoparticles by Pseudomonas alcaliphila. Colloids and Surfaces B: Biointerfaces, 88, 196-201. https://doi.org/10.1016/j.colsurfb.2011.06.031

4. Curran, S. (2004) Structural and Spectral Features of Selenium Nanospheres Produced by Se-Respiring Bacteria. Applied and Environmental Microbiology, 70, 52-60. https://doi.org/10.1128/AEM.70.1.52-60.2004

5. Choudhury, Y., Toh, Y.C., Xing, J., Qu, Y., Poh, J., Huan, L., Tan, H.S., Kanesvaran, R., Yu, H. and Tan, M.-H. (2017) Patient-Specific Hepatocyte-Like Cells Derived from Induced Pluripotent Stem Cells Model PazopanibMediated Hepatotoxicity. Scientific Reports, 7, 41238. https://doi.org/10.1038/srep41238

6. Ramsay, R.R., Rashed, M.S. and Nelson, S.D. (1989) In Vitro Effects of Acetaminophen Metabolites and Analogs 
on the Respiration of Mouse Liver Mitochondria. Archives of Biochemistry and Biophysics, 273, 449-457. https://doi.org/10.1016/0003-9861(89)90504-3

7. Zhao, P., Kalhorn, T.F. and Slattery, J.T. (2002) Selective Mitochondrial Glutathione Depletion by Ethanol Enhances Acetaminophen Toxicity in Rat Liver. Hepatology, 36, 326-335. https://doi.org/10.1053/jhep.2002.34943

8. Kitteringham, N.R., Powell, H., Jenkins, R.E., Hamlett, J., Lovatt, C., Elsby, R., Henderson, C.J., Wolf, C.R., Pennington, S.R. and Park, B.K. (2003) Protein Expression Profiling of Glutathiones-Transferase Pinull Mice as a Strategy to Identify Potential Markers of Resistance to Paracetamol-Induced Toxicity in the Liver. Proteomics, 3, 191-207. https://doi.org/10.1002/pmic.200390028

9. Lee, W.M. (2007) Acetaminophen Toxicity: Changing Perceptions on a Social/Medical Issue. Hepatology, 46, 966-970. https://doi.org/10.1002/hep.21926

10. Saito, C., Zwingmann, C. and Jaeschke, H. (2009) Novel Mechanisms of Protection against Acetaminophen Hepatotoxicity in Mice by Glutathione and N-Acetylcysteine. Hepatology, 51, 246-254. https://doi.org/10.1002/hep.23267

11. Hoque, R., Sohail, M.A., Salhanick, S., Malik, A.F., Ghani, A., Robson, S.C. and Mehal, W.Z. (2012) P2X7 Receptor-Mediated Purinergic Signaling Promotes Liver Injury in Acetaminophen Hepatotoxicity in Mice. American Journal of Physiology-Gastrointestinal and Liver Physiology, 302, G1171-G1179. https://doi.org/10.1152/ajpgi.00352.2011

12. Mohar, I., Stamper, B.S., Rademacher, P.M., White, C.C., Nelson, S.D. and Kavanagh, T.J. (2014) Acetaminophen Induced Liver Damage in Mice Is Associated with Gender-Specific Adduction of Peroxiredoxin-6. Redox Biology, 2, 377-387. https://doi.org/10.1016/j.redox.2014.01.008

13. Barman, P.K., Mukherjee, R., Prusty, B.K., Suklabaidya, S., Senapati, S. and Ravindran, B. (2016) Chitohexaose Protects against Acetaminophen-Induced Hepatotoxicity in Mice. Cell Death and Disease, 7, Article ID: e2224. https://doi.org/10.1038/cddis.2016.131

14. Dkhil, M.A., Bauomy, A.A., Diab, M.S.M. and Al-Quraishy, S. (2016) Protective Role of Selenium Nanoparticles against Schistosoma mansoni Induced Hepatic Injury in Mice. Biomedical Research, 27, 214-219.

15. El-Ghazaly, M.A., Fadel, N., Rashed, E., El-Batal, A. and Kenawy, S.A. (2017) Anti-Inflammatory Effect of Selenium Nanoparticles on the Inflammation Induced in Irradiated Rats. Canadian Journal of Physiology \& Pharmacology, 95, 101-110. https://doi.org/10.1139/cjpp-2016-0183

16. Dakrory, A.I., Fahmy, S.R., Soliman, A.M., Mohamed, A.S. and Amer, S.A.M. (2015) Protective and Curative Effects of the Sea Cucumber Holothuria atra Extract against DMBA-Induced Hepatorenal Diseases in Rats. BioMed Research International.

17. Lampis, S., Zonaro, E., Bertolini, C., Cecconi, D., Monti, F., Micaroni, M., Turner, R.J., Butlerm C.S. and Vallini, G. (2016) Selenite Biotransformation and Detoxification by Stenotrophomonas maltophilia SeITE02: Novel Clues on the Route to Bacterial Biogenesis of Selenium Nanoparticles. Journal of Hazardous Materials, 324, 314. https://doi.org/10.1016/j.jhazmat.2016.02.035

18. Shakibaie, M., Forootanfar, H., Golkari, Y., Mohammadi-Khorsand, T. and Shakibaie, M.R. (2015) Anti-Biofilm Activity of Biogenic Selenium Nanoparticles and Selenium Dioxide against Clinical Isolates of Staphylococcus Aureus, Pseudomonas aeruginosa, and Proteus mirabilis. Journal of Trace Elements in Medicine and Biology, 29, e235-e241. https://doi.org/10.1016/j.jtemb.2014.07.020

19. Amer, S.A.M., AL-Harbi, M.S. and AL-Zahrani, Y.A.A. (2016) Protective Role of Some Antioxidants on Arsenic Toxicity in Male Mice: Physiological and Histopathological Perspectives. Biology and Medicine, 8, 1. https://doi.org/10.4172/0974-8369.1000266

20. Bancroft, J.D., Stevens, A. and Turner, D.R. (1996) Theory and Practice of Histological Techniques. 4th Edition, Churchill Livingstone, London, Toronto. 
21. Mishra, R.R., Prajapati, S., Das, J., Dangar, T.K., Das, N. and Thatoi, H. (2011) Reduction of Selenite to Red Elemental Selenium by Moderately Halotolerant Bacillus megaterium Strains Isolated from Bhitarkanika Mangrove Soil and Characterization of Reduced Product. Chemosphere, 84, e1231-e1237. https://doi.org/10.1016/j.chemosphere.2011.05.025

22. AL-Harbi, M.S., El-Deeb, B.A., Mostafa, N. and Amer, S.A.M. (2014) Extracellular Biosynthesis of Ag NPs by the Bacterium Proteus Mirabilis and Its Toxic Effect on Some Aspects of Animal Physiology. Advances in Nanoparticles, 3, 83-91. https://doi.org/10.4236/anp.2014.33012

23. Oleaga, C., Bernabini ,C., Smith, A.S.T., Srinivasan, B., Jackson, M., McLamb, W., Platt, V., Bridges, R., Cai, Y., Santhanam, N., Berry, B., Najjar, S., Akanda, N., Guo, X., Martin, C., Ekman, G., Esch, M.B., Langer, J., Ouedraogo, G., Cotovio, J., Breton, L., Shuler, M.L. and Hickman, J.J. (2016) Multi-Organ Toxicity Demonstration in a Functional Human in Vitro System Composed of Four Organs. Scientific Reports, 6, 20030. https://doi.org/10.1038/srep20030

24. Benko, I., Nagy, G., Tanczos, B., Ungvari, E., Sztrik, A., Eszenyi, P., Prokisch, J. and Banfalvi, G. (2012) Subacute Toxicity of Nano-Selenium Compared to Other Selenium Species in Mice. Environmental Toxicology and Chemistry, 31, 2812-2820. https://doi.org/10.1002/etc.1995

25. Chun, L.J., Tong, M.J., Busuttil, R.W. and Hiatt, J.R. (2009) Acetaminophen Hepatotoxicity and Acute Liver Failure. Journal of Clinical Gastroenterology, 43, 342-349. https://doi.org/10.1097/MCG.0b013e31818a3854

26. Yousef, M.I., Omar, S.A., El-Guendi, M.I. and Abdelmegid, L.A. (2010) Potential Protective Effects of Quercetin and Curcumin on Paracetamol-Induced Histological Changes, Oxidative Stress, Impaired Liver and Kidney Functions and Haematotoxicity in Rat. Food and Chemical Toxicology, 48, 3246-3261. https://doi.org/10.1016/j.fct.2010.08.034

27. Mossa, A.T.H., Heikal, T.M. and Omara, E.A.A. (2012) Physiological and Histopathological Changes in the Liver of Male Rats Exposed to Paracetamol and Diazinon. Asian Pacific Journal of Tropical Biomedicine, 2, S1683S1690. https://doi.org/10.1016/s2221-1691(12)60478-x

28. Hamza, R.Z. and AL-Harbi, M.S. (2015) Silymarin and Nigella Sativa Extract Ameliorate Paracetamol Induced Oxidative Stress and Renal Dysfunction in Male Mice. Asian Pacific Journal of Tropical Disease, 5, 521-531. https://doi.org/10.1016/j.apjtb.2015.03.011

29. Dehkordi, K.K. (2014) Effect of Selenium Nano-Particle on the Hepatic Changes in Rat. World Journal of Zoology, 9, 1-3.

\section{Scientific Research Publishing}

\section{Submit or recommend next manuscript to SCIRP and we will provide best service for you:}

Accepting pre-submission inquiries through Email, Facebook, LinkedIn, Twitter, etc.

A wide selection of journals (inclusive of 9 subjects, more than 200 journals)

Providing 24-hour high-quality service

User-friendly online submission system

Fair and swift peer-review system

Efficient typesetting and proofreading procedure

Display of the result of downloads and visits, as well as the number of cited articles

Maximum dissemination of your research work

Submit your manuscript at: http://papersubmission.scirp.org/

Or contact ns@scirp.org 